\title{
Principal Transformational Leadership and Teachers' Motivation
}

\author{
Abdul Ghani Kanesan Abdullah ${ }^{1}$, Ying-Leh Ling ${ }^{2} \&$ Shamihah Binti Sufi ${ }^{1}$ \\ ${ }^{1}$ Universiti Sains Malaysia, Malaysia \\ ${ }^{2}$ Politeknik Kuching Sarawak, Malaysia \\ Correspondence: Ying-Leh Ling, Politeknik Kuching Sarawak, Malaysia.
}

Received: January 17, 2018

doi:10.20849/aes.v3i1.316
Accepted: February 26, 2018

Online Published: February 28, 2018

\begin{abstract}
This descriptive study aims to identify the relationship between the principal leadership and motivation among the national school teachers in the town of Nibong Tebal, Penang, Malaysia. A total of 283 teachers via random sampling method were chosen from twenty-one national school in the district of Seberang Perai Selatan, Penang. The questionnaires constructed by Leithwood and Jantzi (1999) and adapted by Anandan (2011) have been used to measure the principal transformational leadership. The questionnaire of Teacher Motivation Questionnaire by Chung (2012) was used to measure work motivation among teachers. The findings presented that the transformational leadership in the teacher's perspective is very high while the work motivational level among the teachers is high as well. The findings show that there are significant differences in both leadership style and teacher motivation towards teachers' gender. Relationship analysis also indicated that there was a significant positive correlation between transformational leadership and teachers' work motivation. Regression analysis also displayed that the best predictor of teachers' motivation is the individual support in transformational leadership. In conclusion, this study recommends that principals should be competent in applying transformational leadership to improve teachers' innovation in accordance with the school suitability and the needs of the situation.
\end{abstract}

Keywords: principal transformational leadership, teachers' motivation

\section{Introduction}

The Malaysian Education Development Plan was launched in 2013 by the Ministry of Education Malaysia (MOE). It is a major change in the twelve year education system from 2013 to 2025. Understanding the fact that the performance of Malaysian students is low according to the 2011 International Mathematics and Science Education Trend Report, the International Students Assessment Program (PISA) Report for 2009 and 2015 as well, triggering the ministry to focus on the need to provide and develop high-performing principals to improve student achievement (Ministry of Education, 2013). This action should be taken in view of the fact that effective school formation requires the high performing principals' leadership (Day, 2011).

However, the effectiveness of educational organizations is not merely dependent on leaders alone (Ling, Abdul Ghani Kanesan, \& Fairuz, 2015). This is because teachers as individuals in schools also play an important role as a motivator in achieving the government's aspirations and improving the quality of education in order to compete with other developed countries. Thus, the motivation of teachers is a major driving factor and should not be neglected as it contributes to the success of the production of high quality productivity (Ames, 1990). In this case, the principals' leadership is seen as a process that seeks the collaboration of teachers in achieving the goals that have been determined. Principals need teachers for the implementation of the planned activities for the good of the school. It is therefore the accountability of principals to take into account the welfare of teachers in school so that teachers' motivation and commitment are sustainable and avoid displeasure with the tasks assigned by the organization (Lokman \& Mohd. Anuar, 2011).

The rapid change in globalization in the education system is now a challenge faced by teachers and this has led teachers to stress. High pressure can cause teachers to be less motivated and they will not be dynamic when conducting teaching and learning at school (Shambani, 2013). This situation also interferes with the focus of the teachers in performing tasks, teachers' relationships at school and can affect the teaching and learning process of students and school achievements (Karsenti \& Collin, 2013). Abdul-Aziz, Chan and Lim (2004) explained that there were some symptoms that lead to subordinates with low motivational work such as increased absenteeism, 
employees are late and early in the workplace, workers show low quality of work, conflicts among members of the organization as well as conflict with the management, rejecting the change and being apart from the unpleasant relationship between other parts of the organization.

It is therefore the responsibility of the principal as a leader in the school to encourage others to use the abilities and resources available to the maximum possible level (Eyal \& Roth, 2010). Administrators who practice effective leadership styles can increase teacher motivation. Various efforts are undertaken by the government to improve the efficiency of the principals from the process of appointment, course and training, assessment and development to ensure the success of the school (Leithwood, Louis, Anderson, \& Wahlstrom, 2004). The country needs a highly cultured, efficient and productive workforce, especially teachers to undertake efforts to achieve the vision and goal of 2020. Hence, the principals are responsible for guiding and mobilizing teachers towards them (Lokman, M Al-Muzammil, \& Chua, 2009).

In general, this study is to examine the relationship between the leadership style of the principals and the motivation of teachers in national schools in the district of Seberang Perai Selatan, Penang, Malaysia. In particular, the objectives of this study are

(a) Identify the level of principal's transformation leadership.

(b) Identify the level of motivation of school teachers.

(c) Identify the differences in transformational leadership practices based on the principals' gender.

(d) Identify differences in teacher motivation based on teachers' gender.

(e) Identify the relationship between principal's transformational leadership and teachers' motivation.

\section{Literature Review}

Transformational leadership emphasizes its followers to act beyond personal interests and prioritize organizational achievement (Bass \& Avolio, 1994). Leaders who practice the transformational leadership style will combine visionary and authentic leadership with the aim of changing the educational environment not only to the school but also the teachers working in it (Waters, 2013). The transformational leader according to Bass (1985) is a leader who can motivate his subordinates to perform more than what they expected to do.

School transformational leadership in this study refers to the principals' effort to motivate teachers in schools to enhance their ability in ensuring the goals of the organization are achieved. There are several dimensions of school transformational leadership model that incorporates some transformational leadership affects the teacher and practice. This includes the vision and mission of the school; intellectual stimulation; individual support; symbol, practice of professional value; engagement in decision making; teaching support; and monitor school activities (Leithwood \& Jantzi, 1999; Leithwood \& Jantzi, 20006).

The study of Arokiasamy, Abdul Ghani Kanesan, Mohammad Zohir, and Aziah (2016) shows that the level of transformational leadership practiced by the principals in the school was moderate and the satisfaction of working of primary school teachers was below satisfactory level with a significant relationship between the level of transformational leadership and job satisfaction. This study did not support the study findings by Afsar, Badir, and Saeed (2014) where transformational leadership is at an extremely high level. Jamalullail, Che Fuzlina, Hazita, and Samsidah (2014) on distributive leadership practices with teachers' motivation to find the level of teacher motivation are at a moderate level. The study by Mustafa and Othman (2016) also discusses the level of teachers' work motivation as a whole at medium to high levels.

The study of Balasubramanian and Krishnan (2012) on transformational leadership towards gender found bank managers of Indian women more practicing transformational leadership than male managers. However, the study of Kent, Blair and Rudd (2010) which examines the differences between men and women leaders in the behavior of managerial leadership transformation companies in China found that the way male leaders and women leaders are the same. The findings of Inayatullah and Jehangir (2012) also found that there was a difference in the motivation of teachers based on gender which showed that the level of motivation among female teachers was higher than that of male teachers in school as well as by Mustafa and Norasmah (2010) that teachers and job performance based on gender indicates that female teachers work motivation is higher.

Review by Othman and Wanlabeh (2012) found that there was a positive relationship between transformational leadership styles with teacher motivation. Similar findings were found in the Eyal and Roth (2011) study which stated that the leadership style of the school principals had a significant relationship with teacher motivation. The results of Kappen (2010) found that overall, transformational leadership has a positive contribution to the motivation and there was a positive relationship with intrinsic motivation. This is because the concept of 
transformational leadership encompasses the aspect of internal focus and emphases on the whole process, not just the result.

Nurharani, Norshidah and Afni Anida (2013) studies showed that transformational leadership forecasters, i.e. individual support, have a modest and positive relationship with organizational commitment. Similarly, the study of Yu, Leithwood and Jantzi (2002) found that individual support forecasters recorded the lowest mean score compared to the mean score of seven transformational leadership forecasters.

\section{Research Methodology}

The data for this study were obtained from 283 trained teachers randomly selected from 21 national schools in the district of Seberang Perai Selatan, Penang using questionnaires. The questionnaires adapted by Anandan (2011) and developed by Leithwood and Jantzi (1999) containing 34 items were used to measure the transformational leadership practiced by the principals at the school. While Teacher's Motivation Questionnaire (TMQ) translation questionnaire (TMQ) by Chung (2012) contains 43 items used to measure teachers' motivation. All items in the questionnaire used five point Likert scale to evaluate the sample response in this study.

\section{Research Findings}

The determination of teacher leadership and teacher motivation was done through descriptive analysis involving mean score and standard deviation and the findings are shown in Table 1 below.

Table 1. Descriptive statistics for mean score and standard deviation over variables

\begin{tabular}{lcc}
\hline \multicolumn{1}{c}{ Variable } & Mean $(\mathrm{M})$ & Standard Deviation \\
\hline Transformational Leadership & $\mathbf{4 . 3 3}$ & $\mathbf{. 4 6}$ \\
School vision and mission & 4.39 & .48 \\
Intellectual stimulation & 4.34 & .51 \\
Individual support & 4.23 & .64 \\
Symbol of Practice and Professional Value & 4.33 & .54 \\
Involvement in Decision Making & 4.27 & .61 \\
Instructional Support & 4.28 & .54 \\
Monitor School Activities & 4.44 & .41 \\
Teacher Motivation & $\mathbf{4 . 3 6}$ & $\mathbf{. 3 1}$ \\
Intrinsic & 4.41 & .33 \\
Extrinsic & 4.29 & .37 \\
\hline
\end{tabular}

Overall, the mean score obtained for the variables of transformational leadership is 4.33 . This finding explained levels above 4.23. Additionally, finding also presented that from the perspective of teachers, teachers were found to be practicing schools' vision and mission, intellectual stimulation, individual support, practice symbols and professional values, decision-making engagements, supporting teaching and monitoring school activities at a very high level $(4.21 \leq \mathrm{M} \leq 5.00)$. Overall, the principals' transformational leadership in this study were at very high level. The findings showed that the mean score of teachers' motivation was 4.29 to 4.41 . The respondents of this study indicated that high agreement on intrinsic motivation $(\mathrm{M}=4.41, \mathrm{SD}=.33)$, extrinsic motivation $(\mathrm{M}=$ $4.29, \mathrm{SD}=.37$ ). This indicated that the dimension of teachers' motivation in this study is high.

Table 2 displayed the mean score obtained by the female principals were lower than the mean score obtained by the male principal in all dimensions of leadership style of leadership transformation. This explains that male principals are more practicing transformational leadership styles in all aspects than female principals. Nevertheless, this statistical test has shown statistically significant differences in dimensions of transformational leadership except the dimension of monitoring school activities. 
Table 2. Transformation leadership differences according to teacher's gender

\begin{tabular}{|c|c|c|c|c|c|}
\hline Transformational Leadership Dimension & Gender & $\mathrm{N}$ & Mean & $\begin{array}{l}\text { Standard } \\
\text { Deviation }\end{array}$ & $t$-value \\
\hline School vision and mission & Male & 130 & 4.50 & .361 & $4.101 * *$ \\
\hline Intellectual stimulation & Female & 153 & 4.28 & .535 & \\
\hline Individual support & Male & 130 & 4.46 & .357 & $3.688 * *$ \\
\hline Symbol of Practice and Professional Value & Female & 153 & 4.24 & .600 & \\
\hline Involvement in Decision Making & Male & 130 & 4.40 & .430 & $4.257 * *$ \\
\hline Instructional Support & Female & 153 & 4.08 & .740 & \\
\hline Monitor School Activities & Male & 130 & 4.49 & .317 & $4.916 * *$ \\
\hline School vision and mission & Female & 153 & 4.1907 & .635 & \\
\hline \multirow{2}{*}{$\begin{array}{l}\text { Intellectual stimulation } \\
\text { Individual support }\end{array}$} & Male & 130 & 4.4327 & .375 & $4.185^{* *}$ \\
\hline & Female & 153 & 4.1389 & .721 & \\
\hline \multirow{2}{*}{$\begin{array}{l}\text { Symbol of Practice and Professional Value } \\
\text { Involvement in Decision Making }\end{array}$} & Male & 130 & 4.4246 & .385 & $4.298 * *$ \\
\hline & Female & 153 & 4.1556 & .618 & \\
\hline \multirow[t]{2}{*}{ Instructional Support } & Male & 130 & 4.4800 & .342 & 1.508 \\
\hline & Female & 153 & 4.4065 & .456 & \\
\hline
\end{tabular}

Note: ${ }^{*}$ Sig. at $p<.05$

The findings showed that the mean score obtained by female teachers was lower than the mean score obtained by male teachers in both dimensions of teachers' motivation. This explained that male teachers are more motivated in all aspects than female teachers. However, the test mean score difference by using $t$-test showed that there were significant differences in teacher motivation extrinsic dimension $(t=2.68, p=.00)$ but not significant for the intrinsic dimension $(t=1.73, p=.08)$ at $p<.05$ level.

Table 3. The difference in motivation based on teacher's gender

\begin{tabular}{lccccc}
\hline Teacher Motivation Dimension & Gender & $\mathrm{N}$ & Mean & Standard Deviation & $t$-value \\
\hline Intrinsic motivation & Male & 72 & 4.47 & .32994 & 1.73 \\
& Female & 211 & 4.39 & .32631 & \\
Extrinsic motivation & Male & 72 & 4.39 & .32371 & $2.68^{* *}$ \\
& Female & 211 & 4.26 & .37842 & \\
\hline
\end{tabular}

Note: **Sig. at $p<.05$

The seven dimensions that formed the school's transformation leadership scale were further analysed to determine inter-correlation and its findings are shown in the table below. Based on Table 4, it is found that the Pearson Correlation Coefficient value obtained between transformational leadership dimensions with intrinsic motivation is positive and significant in the range $.293 \leq \mathrm{r} \leq .502$. These findings demonstrate that there is a significant relationship between transformational leadership style of principals and teachers' motivation.

Table 4. Correlation between transformation leadership with motivation

\begin{tabular}{|c|c|c|}
\hline \multirow[t]{2}{*}{ Transformational Leadership } & \multicolumn{2}{|c|}{ Motivation } \\
\hline & Intrinsic & Extrinsic \\
\hline 1. School vision and mission & $.474^{*}$ & $.448^{*}$ \\
\hline 2. Intellectual stimulation & $.494 *$ & $.515^{*}$ \\
\hline 3. Individual support & $.502 *$ & $.594 *$ \\
\hline 4. Symbol of practice and professional value & $.447^{*}$ & $.551 *$ \\
\hline 5. Involvement in decision making & $.390 *$ & $.595 *$ \\
\hline 6. Instructional support & $.400^{*}$ & $.601 *$ \\
\hline 7. Monitor school activities & $.293 *$ & $.407 *$ \\
\hline
\end{tabular}

Note: *Sig. at $p<.01$ 


\section{Discussion, Implication and Conclusion}

This study showed that the level of practice for transformational leadership among principals was very high. The findings of this study were consistent with the study of Afsar et. al. (2014) where transformational leadership and innovative work behavior find leadership transformation by company managers in China to a very high level. This is because the principal in Malaysia has now attended the NPQEL leadership course organized by the MOE. With this exposure, it turns out that the practice of transformational leadership is increasing (Lokman et al., 2009). Even school leaders are now well aware that the care of an educational organization, especially schools depends on leadership (Ling et al., 2015).

The findings of this study indicated that the motivational level of teachers in national schools is at high levels for both intrinsic motivation and extrinsic motivation. However, the findings differed from Jamalullail et al. al. (2013) which examines the motivation of primary school teachers in 12 primary schools around Port Klang, Selangor to find the level of teacher motivation is modest. In fact, this study is also different from the study of Mustafa and Othman (2016) that the level of teacher's work motivation was generally moderate. Leaders who practice the leadership style of transformation tend to act and strive to motivate, influence or meet the subordinate requirements so that they feel more confident and able to achieve more than what is set.

This study found that there was no significant difference in the transformation leadership practices based on the gender of the principal. This means that male and female principals in this study are more often practicing every dimension of transformational leadership style according to the teacher's view. Hence this study supports the study of Kent, Blair, Rudd and Schuele (2010) which found no difference in transformational leadership practices among transformational leaders. Nevertheless, studies conducted by Balasubramanian and Krishnan (2012) found that women's bank managers in India are more practicing transformational leadership than male managers. This distinction is difficult to explain because leadership is a complex process and the ways a transformational leader and follower interact with one another in influencing the organization are different (Burn, 1978).

The study of the relationship between principals' transformation leadership and teachers' motivation showed that there is a positive and significant relationship. The findings of this study supported the study of Azam and Natyada (2012) conducted in private religious schools, South Thailand found that there is a positive relationship between transformational leadership and teacher motivation. The findings of Kappen (2010) found that transformational leadership has a positive contribution with motivation and there was a positive relationship with intrinsic motivation. The transformational leader can establish a 'self-engagement' of value-sharing that motivates the school community to be committed to the vision.

The results of the study have implications for principals because they serve as leaders and accordingly the principals try to influence their teachers to be motivated to carry out their duties at school. The findings also implicate stakeholders to ensure that teachers' quality of service is improved and teachers continue to provide the best quality and service to the community and the nation. Success in making changes to schools depends on the motivation and ability of the principals (Leithwood et al., 2004). In conclusion, it is hoped that through this study, principals can improve the transformational leadership practices and teachers can understand and practice this leadership style at school.

\section{References}

Abdul-Aziz, A.R., Chan, Y.E., \& Lim, Y.M. (2004). Codifying project management best practices: an appraisal of property developers in Malaysia. International Journal of Construction Management, 4(1), 1-15. https://doi.org/10.1080/15623599.2004.10773047

Afsar, B.F., Badir, Y., \& Saeed, B. (2014). Transformational leadership and innovative work behavior. Industrial Management \& Data Systems, 114(8), 1270-1300. https://doi.org/10.1108/IMDS-05-2014-0152

Ames, C. (1990). Motivation: What teachers need to know. Teachers College Record, 91(3), 409-421.

Anandan a/l Kuppan. (2011). Pengaruh efikasi kendiri dan kolektif guru terhadap hubungan antara kepimpinan transformasi sekolah dengan komitmen kualiti pengajaran. (Unpublished doctoral thesis). Universiti Sains Malaysia.

Arokiasamy, A.R.A., Abdullah, A.G.K., Ahmad, M.Z., \& Ismail, A. (2016). Transformational leadership of school principals and organizational health of primary school teachers in Malaysia. Procedia-Social and Behavioral Sciences, 229, 151-157. https://doi.org/10.1016/j.sbspro.2016.07.124 
Balasubramanian, P., \& Krishnan, V.R. (2012). Impact of gender and transformational leadership on ethical behaviors. Great Lakes Herald, 6(1), 48-58.

Bass, B.M. (1985). Leadership and performance beyond expectations. Collier Macmillan.

Bass, B.M., \& Avolio, B.J. (1994). Improving organizational effectiveness through transformational leadership. Sage.

Burns, J.M. (1978). Leadership. Harper \& Row. New York.

Chung, Yeap Yee. (2012). Pengaruh penyeliaan guru besar terhadap motivasi dan kepuasan kerja guru. (Unpublished master's thesis). Universiti Sains Malaysia.

Day, C. (2011). Successful school leadership: Linking with learning and achievement. McGraw-Hill Education (UK). Retrieved from http://files.eric.ed.gov/fulltext/ED565740.pdf

Eyal, O., \& Roth, G. (2011). Principals' Leadership and Teachers' Motivation: Self-Determination Theory Analysis. Journal of Educational Administration, 49(3), 256-275. https://doi.org/10.1108/09578231111129055

Kappen, F. (2010). Leadership and motivation: How leadership-styles contribute to employees' intrinsic and extrinsic motivation. (Unpublished bachelor degree's thesis). Tilburg University.

Karsenti, T., \& Collin, S. (2013). Why are new teachers leaving the profession? Results of a Canada-wide survey. Education, 3(3), 141-149.

Kent, T.W., Blair, C.A., Rudd, H.F., \& Schuele, U. (2010). Gender differences and transformational leadership behavior: Do both German men and women lead in the same way. International Journal of Leadership Studies, 6(1), 52-66.

Leithwood, K., \& Jantzi, D. (1999). Transformational school leadership effects: A replication. School Effectiveness and School Improvement, 10(4), 451-479. https://doi.org/10.1076/sesi.10.4.451.3495

Leithwood, K., \& Jantzi, D. (2006). Transformational school leadership for large-scale reform: effects on students, teachers, and their classroom practices. School Effectiveness and School Improvement, 17(2), 201-227. https://doi.org/10.1080/09243450600565829

Leithwood, K., Louis, K.S., Anderson, S., \& Wahlstrom, K. (2004). How leadership influences student learning: A review of research for the Learning from Leadership Project. New York, NY: Wallace Foundation.

Ling, Y.L., Abdullah, A.G.K., \& Ismail, F. (2015). Feedback Environment and Job Motivation among the Middle Leaders of Educational Organizations. Journal of Education and Training, 3(1), 90-105. https://doi.org/10.5296/jet.v3i1.8415

Lokman, M.T., M Al-Muzammil, Y., \& Chua, L.K. (2009). Keperluan latihan dan kursus kepada guru besar untuk peningkatan profesionalisme. Jurnal Pengurusan dan Kepimpinan Pendidikan. Kementerian Pendidikan Malaysia.

Lokman, Mohd Tahir, \& Mohd, Anuar Abd Rahman. (2011). Orientasi kepemimpinan pengetua sekolah. Penerbit UTM Press.

Mahamad, S. (2013). Gaya kepimpinan guru besar dan motivasi guru: Kajian di dua buah sekolah rendah luar bandar Kota Tinggi. (Unpublished master's thesis). Universiti Teknologi Malaysia.

Ministry of Education Malaysia. (2013). Retrieved from http://Www.Moe.Gov.My/En/Pelan-Pembangunan-Pendidikan-Malaysia-2013-2025

Mustafa, M.N., \& Othman, N. (2016). The effect of work motivation on teacher's work performance in pekanbaru senior high schools, Riau Province, Indonesia. Sosiohumanika, 3(2), 65-72.

Selamat, N., Nordin, N., \& Adnan, A.A. (2013). Rekindle teacher's organizational commitment: the effect of transformational leadership behavior. Procedia-Social and Behavioral Sciences, 90, 566-574. https://doi.org/10.1016/j.sbspro.2013.07.127

Wahab, J.A., Fuad, C.F.M., Ismail, H., \& Majid, S. (2014). Principals' transformational leadership and their relationship with teachers' job satisfaction and teachers' commitments. International Education Studies, 7(13), 40-48. https://doi.org/10.5539/ies.v7n13p40 
Waters, K.K. (2013). The relationship between principals' leadership styles and job satisfaction as perceived by primary school teachers across NSW independent schools. (Unpublished doctoral thesis). Faculty of Education, University Of Wollongong.

Yu, H., Leithwood, K., \& Jantzi, D. (2002). The effects of transformational leadership on teachers' commitment to change in Hong Kong. Journal of Educational Administration, 40(4), 368-389. https://doi.org/10.1108/09578230210433436

\section{Copyrights}

Copyright for this article is retained by the author(s), with first publication rights granted to the journal.

This is an open-access article distributed under the terms and conditions of the Creative Commons Attribution license (http://creativecommons.org/licenses/by/4.0/). 